\title{
PENGARUH MODEL PEMBELAJARAN PROBING PROMPTING BERBANTUAN MEDIA VIDEO TERHADAP HASIL BELAJAR IPA
}

\author{
Gusti Ayu Made Indah Setiawati ${ }^{1}$, I Made Citra Wibawa ${ }^{2}$, I Gusti Ngurah Japa ${ }^{3}$ \\ 1,2,3 Jurusan Pendidikan Guru Sekolah Dasar, FIP \\ Universitas Pendidikan Ganesha \\ Singaraja, Indonesia \\ email : indahsetiawati47@yahoo.com ${ }^{1}$, imadecitra.wibawa@undiksha.ac.id² \\ ngriapa japa@yahoo.co.id ${ }^{3}$
}

\begin{abstract}
Abstrak
Penelitian ini bertujuan untuk mengetahui pengaruh yang signifikan model pembelajaran Probing Prompting berbantuan media video terhadap hasil belajar IPA kelas V Gugus XIV Kecamatan Buleleng Tahun Pelajaran 2017/2018. Penelitian ini adalah penelitian eksperimen semu (quasi eksperiment) dengan rancangan penelitian post-test only control group desain. Populasi penelitian adalah seluruh kelas V SD di Gugus XIV Kecamatan Buleleng. Sampel penelitian adalah SD No. 3 Tukadmungga sebagai kelompok eksperimen dan SD No. 2 Tukadmungga sebagai kelompok kontrol. Metode pengumpulan data menggunakan metode tes dengan instrumen tes hasil belajar IPA. Analisis data dilakukan dengan uji-t menggunakan bantuan SPSS 16 . Hasilnya adalah $t_{\text {hitung }} 3,79$ lebih besar dari $t_{\text {tabel }}$ 2,024. Kemudian dari hasil analisis deskriptif didapat mean kelompok eksperimen lebih besar yaitu 83,9 sedangkan mean kelompok kontrol yaitu 67,6. Dengan demikian dapat diinterpretasikan bahwa model pembelajaran Probing Prompting berbantuan media video berpengaruh signifikan terhadap hasil belajar IPA pada siswa kelas V di Gugus XIV Kecamatan Buleleng.
\end{abstract}

Kata kunci: Probing Prompting, hasil belajar, IPA.

\begin{abstract}
This study aimed to determine the significant effect of probing promting learning model assisted by video on science outcomes of fifth grade Students Gugus XIV Kabupaten Buleleng in 2017/2018 academic year. This research was quasi experiment with post-test only control group design. The population on this study consisted of all of fifth grade students of elementary school in Gugus XIV Kabupaten Buleleng. This study used total sample, so that all the population be involved, they were students in SD No. 3 Tukadmungga as experiment group and SD No. 2 Tukadmungga as a control group. The data collection method used the test instrument of science learning outcomes. The data analysis was done by t-test using SPSS 16 . The result of $t$ count 3.79 is higher than t-table that is 2,024. Based on the results of data analysis, the average score of the experiment group is higher that is 83.9 while the control group is 67,6 . Thus, the learning model of Probing Prompting with video media has significant effect on the science learning outcomes of the students in Grade V Gugus XIV in Kecamatan Buleleng.
\end{abstract}

Keywords: Probing Prompting, Learning Outcomes, Science 


\section{Pendahuluan}

Pendidikan dalam arti luas dapat diartikan sebagai faktor yang sangat penting yang dapat menunjang kemajuan bangsa, karena melalui pendidikan sumber daya manusia (SDM) yang unggul dan berkualitas dapat tercipta, yang nantinya akan membangun dan membuat bangsa tersebut menjadi bangsa yang maju. Putra (2016) menyatakan, "pendidikan merupakan cermin bagi kemajuan suatu bangsa". Pendidikan yang menjadi pondasi kuat berkembangnya suatu negara adalah pendidikan yang bermutu. Harisanti (2016) menyatakan, pendidikan bermutu adalah "pendidikan yang mampu menghasilkan manusia dengan pribadi yang integral yaitu mereka yang mampu mengitegrasikan iman, ilmu, dan amal".

Dalam upaya meningkatkan mutu pendidikan, pemerintah khususnya Departemen Pendidikan Nasional terus menerus berupaya melakukan berbagai perubahan dan pembaharuan sistem pendidikan. Salah satu upaya yang sudah dilakukan berkaitan dengan guru adalah lahirnya Undang-undang No.14 tahun 2005 tentang Guru dan Dosen. Pada dasarnya undang-undang Guru dan Dosen merupakan kebijakan pemerintah yang memuat usaha pemerintah untuk menata dan memperbaiki mutu guru di Indonesia. "Undang-undang Guru dan Dosen menyatakan bahwa sertifikasi sebagai bagian dari peningkatan mutu dan peningkatan kesejahteraannya" (Muslich, 2007:7). Dalam upaya meningkatkan mutu pendidikan, aspek utama yang ditentukan adalah kualitas guru. Untuk itu, upaya awal yang dilakukan dalam meningkatkan kualitas guru perlu dilakukan peningkatan mutu profesi seorang guru baik secara formal maupun informal. Dalam bidang profesi, seorang guru profesional berfungsi untuk mengajar, mendidik, melatih dan melaksanakan penelitian masalah-masalah pendidikan. Sedangkan pendidikan juga tidak terlepas dari aktivitas yang disebut dengan belajar.

Dari berbagai upaya yang dilakukan pemerintah, harapan pemerintah untuk memajukan kualitas pendidikan secara merata di Indonesia masih belum tercapai. Mutu pendidikan Indonesia masih jauh tertinggal dibandingkan dengan negara-negara lainnya. Menurut Prameswari (dalam Swarjawa, 2013) hal ini dibuktikan oleh "hasil penelitian dari UNDP (United Nation Development Program) bahwa posisi Indonesia dalam indeks pembangunan sumber daya manusia berada pada peringkat 119 dari 187 negara di dunia". Sejalan dengan itu data laporan UNESCO (Education For All Global Monitoring Report) yang dicatat oleh Kemenkopmik (2014), menyatakan "negara Indonesia menempati peringkat 57 dari 115 negara pada tahun 2014" (dalam Putra, 2016). Hal tersebut membuktikan bahwa pendidikan di Indonesia masih tergolong rendah.

Perbaikan kualitas pembelajaran tidak terlepas dari peran guru dalam memilih model pembelajaran yang sesuai untuk terciptanya suasana belajar yang kondusif, sehingga dapat meningkatkan pemecahan masalah siswa dalam belajar, yang pada akhirnya berdampak pada peningkatan mutu pendidikan. Dalam merancang pembelajaran, seorang guru harus memperhatikan tujuan diselenggarakannya pembelajaran itu sendiri, termasuk di dalamnya pembelajaran IPA (IImu Pengetahuan Alam).

IImu Pengetahuan Alam (IPA) adalah salah satu mata pelajaran yang dipelajari oleh siswa di Sekolah Dasar. Pembelajaran IPA menjadi wahana bagi siswa mengembangkan dan menumbuhkan inovasi, kreativitas, dan kemampuan berpikir guna menghadapi masa depan yang penuh tantangan. Swarjawa (2013) mengemukakan IPA merupakan "mata pelajaran yang mendasari perkembangan teknologi dan konsep hidup harmonis dengan alam". Rahayu (2012) menyatakan, "IPA atau sains merupakan ilmu yang mempelajari gejala-gejala alam yang meliputi mahluk hidup dan mahluk tak hidup atau sains tentang kehidupan dan sains tentang dunia fisik". IPA menekankan pada pemberian pengalaman langsung untuk mengembangkan kompetensi agar siswa mampu menjelajahi dan memahami alam sekitar secara ilmiah. Selain itu IPA juga merupakan ilmu yang membahas tentang fakta serta gejala alam. Fakta dan gejala alam tersebut menjadikan pembelajaran IPA tidak hanya verbal tetapi juga faktual. Hal ini menunjukkan bahwa, hakikat IPA sebagai suatu proses diperlukan untuk menciptakan 
pembelajaran IPA yang empirik dan faktual. Menurut Riastini, dkk (2016:1) mengatakan "hakikat IImu Pengetahuan Alam adalah sebagai produk, proses dan sikap ilmiah".

Hasil belajar merupakan perubahan prilaku yang diperoleh siswa setelah melewati kegiatan belajar. Sebagaimana yang dikemukakan Dimyati dan Moedjiono (2015:3) menyatakan bahwa "hasil belajar merupakan hasil dari suatu interaksi tindak belajar atau tindak mengajar. Benyamin S Bloom (dalam Swarjawa, 2016) "mengelompokkan hasil belajar menjadi tiga ranah yaitu ranah kognitif, afektif, dan psikomotor". Hasil belajar kognitif merupakan tingkat pemahaman siswa terhadap materi. Hasil belajar afektif lebih berorientasi pada pembentukan sikap melalui proses pembelajaran. Sedangkan hasil belajar psikomotor berkaitan dengan hasil kemampuan fisik siswa. Diantara ketiga ranah tersebut, ranah kognitif yang paling banyak dinilai oleh para guru di sekolah karena berkaitan dengan kemampuan para siswa dalam menguasai isi bahan pembelajaran. Berdasarkan pernyataan tersebut, dalam konteks penelitian ini yang dimaksud dengan hasil belajar adalah hasil yang diperoleh siswa setelah mengalami interaksi proses pembelajaran dan diberikan tes berupa pilihan ganda. Tes yang digunakan adalah tes untuk mengukur pada ranah kognitif saja.

Dalam belajar tentunya ada beberapa faktor yang mempengaruhi. Menurut Dimyati dan Mudjiono (2015:236-253) faktor-faktor yang mempengaruhi siswa dalam belajar ada dua, yaitu faktor intern dan ekstern. Faktor intern, yaitu sikap terhadap belajar, motivasi belajar, konsentrasi belajar, kemampuan mengolah bahan belajar, cara menyimpan perolehan hasil belajar, cara menggali hasil belajar yang tersimpan, kemampuan berprestasi atau unjuk kerja, rasa percaya diri siswa, intelegensi, kebiasaan belajar, cita-cita. Faktor ekstern, yaitu guru sebagai pembina siswa, prasarana dan sarana pembelajaran, kebijakan penilaian, lingkungan sosial siswa di sekolah, kurikulum sekolah.

Penelitian ini didasarkan atas permasalahan hasil belajar siswa yang rata-rata masih di bawah KKM dan hal tersebut diakibatkan karena: 1) sebagian besar pembelajaran berorientasi pada materi, guru lebih banyak bergantung pada buku ajar atau LKS, 2) banyak siswa yang kurang memanfaatkan waktu untuk belajar. Itu terlihat saat pembelajaran ada beberapa siswa yang bermain-main. 3) siswa dalam pembelajaran menjadi penerima yang pasif disebabkan karena pola pembelajaran yang masih didominasi oleh guru, 4) masih ada siswa yang yang malu dalam mengungkapkan pendapat mereka yang mengakibatkan hasil belajar siswa kurang, 5) interaksi multi arah dalam pembelajaran sangatlah kurang sehingga pembelajaran terkesan monoton dan membosankan. Terkait temuan di lapangan, maka solusi yang ditawarkan oleh peneliti adalah memilih model pembelajaran Probing Prompting. Menurut Putra (2016) menyatakan "model pembelajaran Probing Prompting memiliki banyak keunggulan untuk membuat siswa aktif dalam proses pembelajaran".

Model pembelajaran Probing Prompting berkaitan erat dengan pertanyaan. Pertanyaanpertanyaan yang disampaikan kepada siswa selama proses pembelajaran disebut probing question. Pertanyaan yang disampaikan kepada siswa, ditujukan untuk memotivasi dan memberikan isyarat kepada siswa dalam memahami serta menemukan jawaban dari permasalahan yang ada secara lebih mendalam. Jenis dan tingkat kesulitan pertanyaan disesuaikan dengan masing-masing siswa. Swarjawa (2013) menyatakan "Probing Prompting adalah suatu model pembelajaran yang berpusat pada pebelajar (student centered)". Swasono (2014) mengemukakan, "melalui Probing Prompting peserta didik dirangsang untuk aktif berpikir dalam merespon setiap pertanyaan yang diajukan".

Proses kegiatan tanya jawab dalam pembelajaran, dilakukan dengan cara menunjuk siswa secara acak, sehingga setiap siswa mau tidak mau harus turut serta berpartisipasi aktif. Menurut Shoimin (dalam Artawan, 2017) menyatakan "model pembelajaran Probing Prompting juga sebagai pembelajaran yang mengacu pada daya berpikir lebih aktif, mengembangkan keterampilan siswa dalam mengemukakan pendapat dan memberikan pengetahuan yang luas kepada siswa". Siswa setiap saat bisa ditunjuk untuk menjawab pertanyaan dari guru. Dalam model pembelajaran Probing Prompting guru mengaitkan materi yang dipelajari dengan pengalaman nyata dan aplikasinya untuk memecahkan masalah dalam kehidupan sehari-hari. Model pembelajaran probing prompting memiliki tujuh fase dalam pembelajaran. Setiap fase menggambarkan kegiatan guru dan siswa dalam proses pembelajaran. Putra (2016), 
menyatakan tujuh fase tersebut yakni "New Situation, Think Opening, Questions, Think Opening, Reply Questions, Screen Comprehension, dan Last Questions" Dengan didukung oleh media video, model pembelajaran Probing Prompting menjadi lebih menyenangkan. Karena melalui mengamati tayangan video yang disajikan siswa juga dapat merasa lebih dekat dan lebih mengenal tentang apa yang sedang dipelajari. Imamah (2012) menyatakan, "kebanyakan orang lebih suka belajar ilmu IPA menggunakan video atau animasi pembelajaran, karena kita akan disajikan sebuah pembelajaran visual yang lebih menarik dan lebih mudah untuk dipelajari". Sejalan dengan pendapat tersebut, Al-idrus (2015) menyatakan "permasalahan yang disajikan melalui media video kartun untuk menampilkan kejadian seharihari dapat merangsang antusias siswa untuk memecahkan masalah dan aktif dalam melakukan penyelidikan". Lebih lanjut Al-idrus juga menyatakan "video kartun sendiri dapat menarik minat, memotivasi dan menarik perhatian siswa dalam mengikuti pembelajaran".

Berdasarkan hal tersebut, maka penelitian dilaksanakan untuk mengetahui pengaruh yang signifikan model pembelajaran Probing Prompting berbantuan media video terhadap hasil belajar IPA kelas V Gugus XIV Kecamatan Buleleng Tahun Pelajaran 2017/2018. Populasi penelitian adalah seluruh kelas V SD di Gugus XIV Kecamatan Buleleng. Penelitian ini mengambil sampel, yaitu seluruh siswa kelas V SD No. 3 Tukadmungga sebagai kelompok siswa yang dibelajarkan dengan model pembelajaran Probing Prompting berbantuan media video dan seluruh siswa kelas V SD No. 2 Tukadmungga sebagai kelompok siswa yang dibelajarkan tidak menggunakan model pembelajaran Probing Prompting berbantuan video.

\section{Metode}

Jenis penelitian yang digunakan dalam penelitian ini adalah penelitian eksperimen semu (quasi eksperiment). Dalam penelitian ini menggunakan "Post-test only control group desain" yang dapat diilustrasikan sebagai berikut.

Tabel 1. Desain Penelitian "Post-test Only Control Group Desain”

\begin{tabular}{c|c|c}
\hline $\mathrm{E}$ & $\mathrm{X}$ & $\mathrm{O}_{1}$ \\
\hline $\mathrm{K}$ & - & $\mathrm{O}_{2}$ \\
\hline \multicolumn{2}{|c}{ Sumber: Agung (dalam Artawan, 2017) }
\end{tabular}

Keterangan:

$\mathrm{E}:$ Kelompok eksperimen

$\mathrm{K}$ : Kelompok kontrol

$X$ : Perlakuan, yaitu modelpembelajaran Probing Prompting Berbantuan Video

$\mathrm{O}_{1}$ :Test akhir (post-test) kelompok eksperimen

$\mathrm{O}_{2}$ :Test akhir (post-test) kelompok kontrol

Dalam penelitian ini terdapat satu variabel bebas dan satu variabel terikat. Variabel bebas tersebut adalah model pembelajaran Probing Prompting berbantuan media video dan variabel terikat adalah hasil belajar IPA. Populasi dalam penelitian ini adalah seluruh siswa kelas V SD di Gugus XIV Kecamatan Buleleng. Penelitian ini adalah penelitian eksperimen semu dengan jumlah sampel 40 siswa. Dari populasi yang ada, ditentukan sampel dengan teknik random sampling untuk menentukan kelas eksperimen dan kelas kontrol. Sebelum menentukan kelompok eksperimen dan kelompok kontrol, terlebih dahulu melakukan uji kesetaraan kelas dengan menggunakan Anava satu jalur. Setelah dilakukan uji kesetaraan, kelompok eksperimen dan kelompok kontrol ditentukan dengan cara pengundian. Dari hasil pengundian diperoleh hasil kelas V SD No. 3 Tukadmungga sebagai kelompok eksperimen dan kelas V SD No. 2 Tukadmungga sebagai kelompok kontrol. Kelompok kontrol diberikan perlakuan model pembelajaran Probing Prompting berbantuan media video, sedangkan kelompok kontrol dibelajarkan tanpa menggunakan model pembelajaran Probing Prompting berbantuan media video. Pelaksanaan eksperimen dilaksanakan mulai tanggal 26 Maret 
sampai 25 April 2018. Pertemuan dilaksanakan sebanyak 8 kali yang terdiri dari 7 kali pembelajaran dengan model pembelajaran Probing Prompting berbantuan media video dan satu kali post-test. Pelaksanaan kontrol dilakukan mulai tanggal 29 Maret sampai 27 April 2018. Pertemuan dilaksanakan sebanyak 8 kali yang terdiri dari 7 kali pembelajaran tanpa mendapat perlakuan model pembelajaran Probing Prompting berbantuan media video dan 1 kali posttest. Sebelum melakukan post-test hasil belajar IPA dikumpulkan dengan melakukan uji coba instrumen. Uji coba instrumen digunakan untuk mengetahui validitas, reliabilitas, tingkat kesukaran, dan daya beda sehingga soal yang akan digunakan post-test di kelas eksperimen dan kelas kontrol layak untuk digunakan. Hasil penelitian dianalisis dengan statistik inferensial. Uji prasyarat yang dilakukan adalah uji normalitas sebaran data dan uji homogenitas varians. Analisis yang digunakan untuk menguji hipotesis adalah perhitungan uji-t.

\section{Hasil dan Pembahasan}

Pada penelitian ini peneliti menggunakan metode pengumpulan data yaitu metode tes, untuk memperoleh data hasil belajar kelas V Gugus XIV Kecamatan Buleleng berupa skor (data interval) dari kelas eksperimen dan kelas kontrol. Berdasarkan hasil belajar siswa mean pada hasil belajar IPA kelompok siswa yang belajar menggunakan model pembelajaran Probing Prompting berbantuan video adalah 83,9 dan mean pada hasil belajar kelas yang dibelajarkan tidak dengan model pembelajaran Probing Prompting berbantuan video adalah 67,6. Kemudian grafik hasil belajar IPA kelompok eksperimen tersebut dapat disajikan ke dalam bentuk grafik poligon seperti pada Gambar 1.

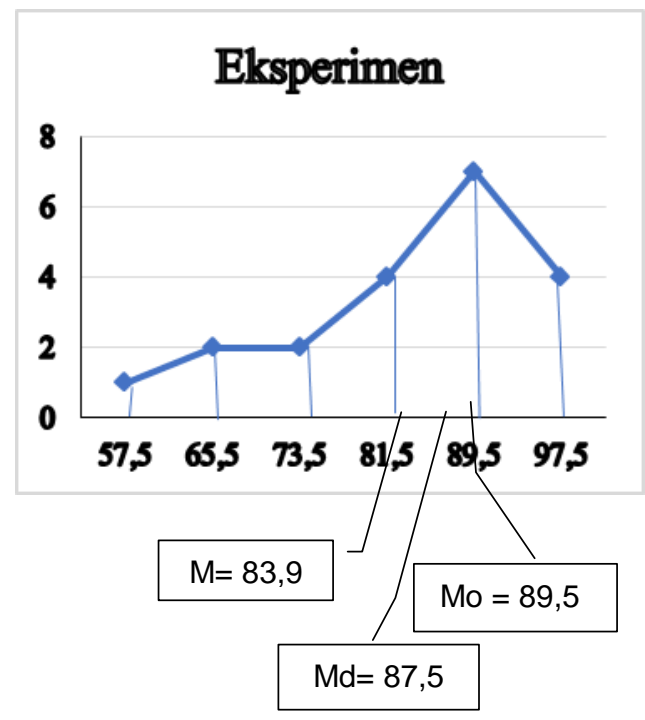

Gambar 1. Kurva Poligon Distribusi Frekuensi Kelompok Eksperimen

Berdasarkan kurva poligon distribusi frekuensi hasil belajar IPA kelompok eksperimen di atas, dapat diketahui modus lebih besar dari mean dan median lebih besar dari mean $(\mathrm{Mo}>\mathrm{Md}>\mathrm{M})$. Dengan kata lain, kurva di atas adalah kurva juling negatif. Artinya, sebagian besar skor cenderung tinggi. Sedangkan data hasil belajar IPA kelompok kontrol dapat disajikan ke dalam kurva poligon seperti pada Gambar 2. 


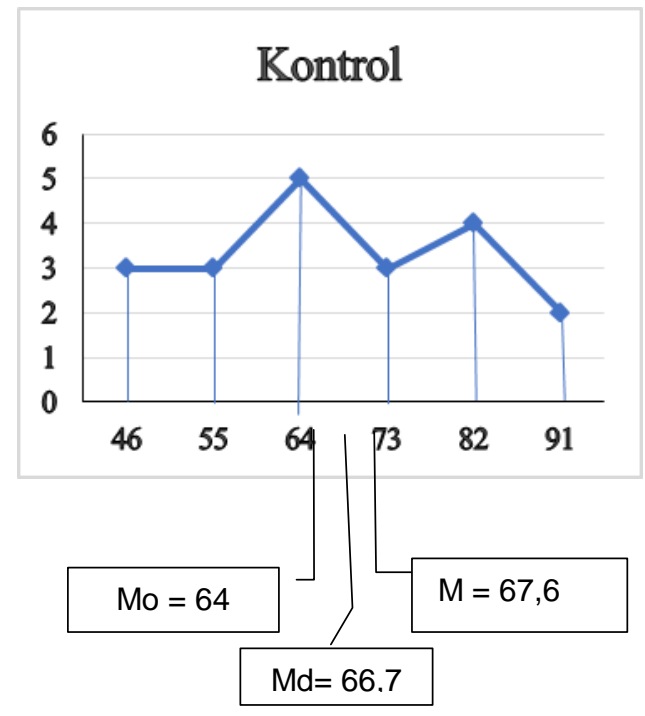

\section{Gambar 2. Kurva Poligon Distribusi Frekuensi Kelompok Kontrol}

Berdasarkan kurva poligon distribusi frekuensi hasil belajar IPA kelompok kontrol di atas, dapat diketahui mean lebih besar dari modus dan median lebih besar dari modus ( $\mathrm{M}>\mathrm{Md}>\mathrm{Mo}$ ). Dengan kata lain, kurva di atas,adalah kurva juling positif. Artinya, sebagian besar skor cenderung rendah.

Setelah dilakukan post test maka tahap selanjutnya adalah uji normalitas. Uji ini dilakukan untuk mengetahui data tersebut berdistribusi normal atau tidak. Dan pada penelitian ini data berdistribusi normal. Selanjutnya, dilakukan uji homogenitas yang menyatakan data homogen dan yang terakhir dilakukan uji hipotesis.

Analisis data dilakukan dengan uji-t menggunakan bantuan SPSS 16. Hasilnya adalah $t_{\text {hitung }} 3,79$ lebih besar dari $t_{\text {tabel }} 2,024\left(t_{\text {hitung }}>t_{\text {tabel }}\right)$. Hal ini berarti terdapat perbedaan yang signifikan antara kelompok eksperimen dan kelompok kontrol. Sehingga nilai statistik tersebut memiliki makna bahwa terdapat pengaruh yang signifikan model pembelajaran Probing Prompting berbantuan media video terhadap hasil belajar IPA kelas V Gugus XIV Kecamatan Buleleng Tahun Pelajaran 2017/2018. Hal ini diperkuat oleh hasil analisis deskriptif yang sudah dilakukan terhadap hasil post test ditemukan bahwa rata-rata hasil belajar IPA kelompok siswa yang belajar dengan menggunakan model pembelajaran Probing Prompting yang memiliki ratarata 83,9 lebih tinggi dibandingkan dengan rata-rata hasil belajar IPA pada kelompok siswa yang belajar tidak menggunakan model pembelajaran Probing Prompting yang memiliki ratarata 67,6. Rata-rata skor hasil belajar IPA siswa kelompok eksperimen adalah 83,9 berada pada kategori sangat tinggi. Sementara itu, skor hasil belajar IPA siswa kelompok kontrol adalah 67,6 berada pada kategori tinggi.

Perbedaan hasil belajar antara kelompok siswa yang diberikan perlakuan model pembelajaran Probing Prompting berbantuan video dengan kelompok siswa yang tidak diberikan perlakuan model pembelajaran probing Prompting berbantuan video disebabkan oleh beberapa hal. Pertama, pembelajaran dengan model pembelajaran Probing Prompting memberikan kesempatan bagi siswa untuk menanyakan hal hal yang kurang jelas. Pembelajaran ini membuat siswa berpikir lebih aktif. Selain itu, siswa dapat mengembangkan keberanian dalam menjawab dan mengemukakan pendapat. Dengan demikian penguasaan materi siswa menjadi lebih baik, sehingga hasil belajar siswa menjadi lebih baik. Muvawala (dalam Artawan, 2017) menemukan bahwa "model pembelajaran Probing Prompting memiliki faktor yang sangat penting dalam meningkatkan hasil belajar". Fasriyah (dalam Artawan, 2017) menemukan bahwa "model pembelajaran Probing Prompting dapat meningkatkan hasil belajar siswa". 
Kedua, pembelajaran menggunakan model pembelajaran Probing Prompting dibantu dengan media video. Media video merupakan salah satu jenis media yang banyak dikembangkan untuk keperluan pembelajaran. Media video dapat membantu siswa memahami materi pembelajaran apalagi materi pembelajaran yang bersifat abstak, siswa bisa melihat apa yang dipelajari tanpa hanya membayangkan saja. Apalagi siswa SD, belajar sebaiknya menggunakan hal-hal yang brsifat konkret. Hal ini sejalan dengan pendapat Imamah (2012) menyatakan, "kebanyakan orang lebih suka belajar ilmu IPA menggunakan video atau animasi pembelajaran, karena kita akan disajikan sebuah pembelajaran visual yang lebih menarik dan lebih mudah untuk dipelajari". Selain itu, Al-idrus juga menyatakan "permasalahan yang disajikan melalui media video kartun untuk menampilkan kejadian sehari-hari dapat merangsang antusias siswa untuk memecahkan masalah dan aktif dalam melakukan penyelidikan".

Ketiga, pembelajaran menggunakan model pembelajaran Probing Prompting berbantuan video di desain dengan membentuk kelompok agar siswa bekerja sama dalam menyelesaikan permasalahan yang diberikan. Melalui kegiatan diskusi kelompok, siswa secara aktif dan antusias untuk memecahkan masalah yang dihadapi dalam proses pembelajaran. Siswa yang belum mengerti dapat bertanya langsung dengan teman kelompok sehingga menumbuhkan rasa ingin tahu yang tinggi. LKS yang dirancang berupa permasalahan yang ditentukan terkait hasil pembelajaran yang sudah dilakukan sehingga hasil belajar siswa akan lebih maksimal. Hal ini sesuai dengan pendapat Swarjawa (2013) yang menyatakan bahwa "dalam kegiatan diskusi semua siswa aktif, memiliki rasa ingin tahu, dan antusias untuk memecahkan masalah yang dihadapi sehingga siswa akan termotivasi untuk mengikuti pembelajaran".

Selain itu, model pembelajaran Probing Prompting berbantuan video lebih unggul dilihat dari sintaknya pada saat pembelajaran yaitu: 1) new situation (situasi baru) dan think opening (memberikan siswa kesempatan berpikir) mengukur tingkat kognitif 1 dan 2 yaitu pengetahuan dan pemahaman siswa terhadap materi, 2) pada fase questions (persoalan), replay question, screen comprehension, last questions tingkat kognitif yang diukur adalah tingkat kognitif satu sampai dengan tingkat kognitif enam. Hal itu karena saat guru menunjuk siswa secara acak, siswa harus siap menjawab maupun menanggapi permasalahan yang diberikan. Termasuk membuat laporan tentang peristiwa alam yang berdampak bagi makhluk hidup dan lingkungan Indonesia yang ada pada indikator pembelajaran 7.6.6 pada silabus (lampiran 03) yang sudah tergolong dalam tingkat kognitif enam.

Berbeda dengan siswa yang dibelajarkan dengan model pembelajaran Probing Prompting berbantuan video, hasil belajar siswa yang dibelajarkan tidak dengan model pembelajaran Probing Prompting berbantuan video pada kelas kontrol cenderung lebih rendah karena dalam pembelajaran menggunakan cara yang biasa diterapkan oleh guru yang ditandai dengan ceramah serta pembagian tugas dan latihan. Pada saat proses pembelajaran berlangsung siswa lebih banyak mendengarkan dan mencatat hal-hal penting yang disampaikan oleh guru, sehingga dalam proses pembelajaran guru lebih mendominasi yang mengakibatkan siswa cenderung pasif. Pada pembelajaran kelompok kontrol apa yang dipelajari lebih bersifat text book. Oleh sebab itu pembelajaran pada kelas kontrol ini kurang efektif yang menyebabkan siswa cenderung bosan dalam mengikuti pembelajaran, sehingga hasil belajar yang dicapai menjadi kurang maksimal.

Dari uraian teoritik di atas terlihat bahwa hasil belajar siswa yang dibelajarkan dengan model pembelajaran Probing Prompting berbantuan video lebih unggul dibandingkan dengan hasil belajar siswa yang dibelajarkan tidak dengan model pembelajaran Probing Prompting berbantuan video. Model pembelajaran Probing Prompting berbantuan video menuntut interaksi dan partisipasi aktif siswa karena dengan model pembelajaran Probing Prompting siswa harus selalu siap dalam pembelajaran karena sewaktu waktu akan ditunjuk oleh guru untuk menjawab maupun menanggapi pertanyaan dari permasalahan yang ditemukan. Selain itu dengan bantuan media video juga dapat membantu siswa lebih memahami materi karena melalui video siswa lebih dekat dengan apa yang dipelajari tanpa perlu hanya membayangkan materi yang sifatnya abstrak. Untuk anak usia SD, siswa sebagian besar tertarik pada videovideo animasi yang bila dikaitkan dalam pembelajaran pastinya akan lebih menarik minat 
belajar siswa. Apabila siswa aktif dan tertarik dalam kegiatan pembelajaran maka berdampak pada meningkatnya minat belajar dan motivasi belajar siswa, sehingga hasil belajar siswa pun dapat menjadi lebih baik. Walaupun demikian, pada hakikatnya semua model pembelajaran sangat bagus diterapkan, oleh karena itu guru harus pintar memilih model pembelajaran dengan mempertimbangkan seluruh aspek yang terkait sehingga dapat mencapai tujuan pembelajaran secara maksimal.

\section{Simpulan dan Saran}

Berdasarkan hasil pengujian hipotesis dan pembahasan, maka simpulan penelitian ini yaitu terdapat pengaruh yang signifikan model pembelajaran Probing Prompting berbantuan media video terhadap hasil belajar IPA kelas V Gugus XIV Kecamatan Buleleng Tahun Pelajaran 2017/2018. Analisis data dilakukan dengan uji-t menggunakan bantuan SPSS 16. Hasilnya adalah $t_{\text {hitung }} 3,79$ lebih besar dari $t_{\text {tabel }} 2,024\left(t_{\text {hitung }}>t_{\text {tabel }}\right)$. Hal ini diperkuat dari hasil analisis deskriptif, yaitu rata-rata hasil belajar IPA kelompok yang belajar dengan menggunakan model pembelajaran Probing Prompting adalah 83,9 (kategori sangat tinggi) sedangkan rata-rata hasil belajar IPA pada kelompok siswa yang belajar tidak menggunakan model pembelajaran Probing Prompting memiliki rata-rata 67,6 (kategori tinggi). Dengan demikian dapat diinterpretasikan bahwa model pembelajaran Probing Prompting berbantuan media video berpengaruh signifikan terhadap hasil belajar IPA pada siswa kelas V di Gugus XIV Kecamatan Buleleng Tahun Pelajaran 2017/2018. Adapun saran yang ditujukan Kepada kepala sekolah disarankan dapat menjadikan hasil penelitian ini sebagai salah satu strategi untuk meningkatkan hasil belajar siswa. Kepada guru agar menggunakan model pembelajaran probing promting berbantuan media video khususnya dalam mata pelajaran IPA dan mata pelajaran lainnya dalam upaya meningkatkan hasil belajar siswa. Bagi siswa di SD No. 3 Tukadmungga dan SD No.2 Tukadmungga agar rajin belajar, mampu mengembangkan motivasi belajar dan aktif mengikuti pembelajaran melalui penggunaan model pembelajaran probing prompting untuk meningkatkan hasil belajar. Bagi peneliti lain disarankan untuk mengadakan penelitian lebih lanjut tentang model pembelajaran probing prompting dalam bidang Ilmu Pengetahuan Alam maupun bidang ilmu lainnya yang sesuai, agar memperhatikan kendala kendala yang di alami penelitian ini sebagai bahan pertimbangan untuk perbaikan dan penyempurnaan penelitian yang akan dilaksanakan.

\section{Daftar Rujukan}

Al-idrus, S. Q. M. J., Hikmawati, H., \& Wahyudi, W. (2015). Pengaruh Model Pembelajaran Berbasis Masalah Berbantuan Video Kartun Terhadap Hasil Belajar Fisika Siswa Kelas XI SMAN 1 Sikur Tahun Ajaran 2014/2015. Jurnal Pijar MIPA, 10(1).

Artawan, K. A., Gading, I. K., \& Dibia, I. K. (2017). Pengaruh Model Pembelajaran Probing Prompting Terhadap Hail Belajar IPA Pada Siswa Kelas V Sekolah Dasar. MIMBAR PGSD, 5(2) (hlm. 1-10).

Dimyati dan Mudjiono. 2015. Belajar dan Pembelajaran. Jakarta:PT. Rineka Cipta.

Harisanti, P. S., Sunarya, I. M. G., Kom, S., \& Sindu, I. G. P. (2016). Pengaruh Model Pembelajaran Probing Promting Terhadap Motivasi Dan Hasil Belajar Siswa Kelas $X$ Multimedia Pada Mata Pelajaran Sistem Operasi Di SMK Negeri 1 Sukasada. KARMAPATI (Kumpulan Artikel Mahasiswa Pendidikan Teknik Informatika) ISSN: 22529063, 5(2) (hlm. 1-10). 
Imamah, N. (2012). Peningkatan Hasil Belajar IPA Melalui Pembelajaran Kooperatif Berbasis Konstruktivisme Dipadukan Dengan Video Animasi Materi Sistem Kehidupan Tumbuhan. Jurnal Pendidikan IPA Indonesia, 1(1) (hlm. 32-36).

Muslich, Masnur. 2007. Sertifikasi Guru Menuju Profesionalisme Pendidik. Malang: PT Bumi Aksara.

Putra, I. M. B. S., Garminah, N. N., \& Wibawa, I. M. C. (2016). Pengaruh Probing Prompting Terhadap Hasil Belajar IPS dengan Kovariabel Motivasi Berprestasi Pada Siswa Kelas IV. MIMBAR PGSD Undiksha, 4(1) (hlm. 1-10).

Rahayu, P., Mulyani, S., \& Miswadi, S. S. (2012). Pengembangan Pembelajaran IPA Terpadu dengan Menggunakan Model Pembelajaran Problem Base Melalui Lesson Study. Jurnal Pendidikan IPA Indonesia, 1(1) (hlm. 63-70).

Riastini, dkk. 2016. Buku Ajar Pembelajaran IPA SD. Singaraja: Undiksha.

Swarjawa, I. W. E., Suarjana, M., \& Garminah, N. N. (2013). Pengaruh Model Pembelajaran Probing-Prompting Terhadap Hasil Belajar IPA Siswa Kelas V di SD Negeri 1 Sebatu. MIMBAR PGSD, 1 (hlm. 1-11).

Swasono, A. H., Suyitno, A., \& Susilo, B. E. (2014). Penerapan Pembelajaran ProbingPrompting Terhadap Hasil Belajar Peserta Didik Pada Materi Lingkaran. Unnes Journal of Mathematics Education, 3(2) (hlm. 101-106). 